\title{
The beluga whale (Delphinapterus leucas) catches in the White, Barents, and western Kara seas from 1930 based on original sources
}

\author{
Yaroslava I. Alekseeva, Olga V. Shpak* \& Svyatoslav S. Gorbunov
}

\begin{abstract}
The work is based on an analysis of archival documents containing quantitative information on harvests of beluga whales in the White, Barents, and western Kara seas from 1930. Also, information is provided on the possible places where the documents containing data of beluga whaling could still be preserved. The probable causes of the reduction in catches and abundance of beluga whales in the coastal waters of the study areas, observed from the late 1960 s, are discussed.

How to cite this article: Alekseeva Y.I., Shpak O.V., Gorbunov S.S. 2019. The beluga whale (Delphinapterus leucas) catches in the White, Barents, and western Kara seas from 1930 based on original sources //Russian J. Theriol. Vol.18. No.1. P.20-32. doi: 10.15298/rusjtheriol.18.1.03.
\end{abstract}

KEY WORDS: beluga whale, Delphinapterus leucas, commercial harvest, White Sea, Barents Sea, Kara Sea, archival documents.

Yaroslava I.Alekseeva [a-ja@list.ru], K.A. Timiryazev State Biological Museum, Malaya Gruzinskaya 15, Moscow 123242, Russia; Olga V. Shpak [ovshpak@gmail.com], A.N. Severtsov Institute of Ecology and Evolution RAS, Leninsky prospect 33, Moscow 119071, Russia; SvyatoslavS.Gorbunov [svy-gorbunov@yandex.ru], independent researcher, Moscow, Russia.

\section{Документальные данные об уловах белухи (Delphinapterus leucas) в Белом, Баренцевом морях и западной части Карского моря с 1930 г.}

\author{
Я.И. Алексеева, О.В. Шпак, С.С. Горбунов
}

\begin{abstract}
РЕЗЮМЕ: В работе проанализированы архивные документы, содержащие количественные сведения о промысле белухи в морях Белом, Баренцевом и в западной части Карского моря с 1930 года, а также приведены сведения о возможных местах хранения документов, содержащих данные о промысле белухи. Обсуждаются возможные причины снижения уловов и численности белухи с конца 1960-х гг. в прибрежных водах исследуемых акваторий.
\end{abstract}

КЛЮЧЕВЫЕ СЛОВА: белуха, Delphinapterus leucas, промысел, Белое море, Баренцево море, Карское море, архивные документы.

\section{Introduction}

Analysis of long-term dynamics of harvest is one of the ways to assess the carrying capacity of the environment, and provides additional opportunities for evaluating the impacts of anthropogenic and climatic factors on the abundance and distribution of populations.

Annual data on the beluga whale Delphinapterus leucas (Pallas, 1776) catches in the White, Barents, and Kara seas in the $20^{\text {th }}$ century were published by many authors. In addition, there are annual data for certain areas of the White and Barents seas since 1925. Annual statistics on total catches in the White, Barents, and Kara seas are available for certain periods, for each sea separately, and for all the seas (Zhilinskii, 1917: 210-227; Ostroumov, 1935; Golenchenko, 1936; Klumov, 1939; Kleinenberg et al., 1964; Matishov \& Ognetov, 2006).

\footnotetext{
* Corresponding author.
}

It is probable that, previous researchers used the original sources of catch data, but these sources are not indicated in most works. Only in the article by Tarasevich (1960), the author notes that data on beluga catches for 1947-1958 are based on oral reports from hunters and on the statistics from the Shoinsky fish processing plant. The most comprehensive data on annual catches from 1960 to 1989 are available in the work of Ognetov (1999). Same data can also be found in the publication of Boltunov and Belikov (2002), who provided the summarized statistics of catches from 1902 to 1990 . The catch figures for the White, Barents, and Kara seas for 1950-1959 presented by these authors were obtained from materials of the Arkhangelsk Northern Basin Directorate for Conservation and Recovery of Fishery Resources (Sevrybvod) and the Northern Branch of the Polar Research Institute of Fisheries and Oceanography (SevPINRO). These organizations were responsible for regulating the hunt and keeping the detailed records. 


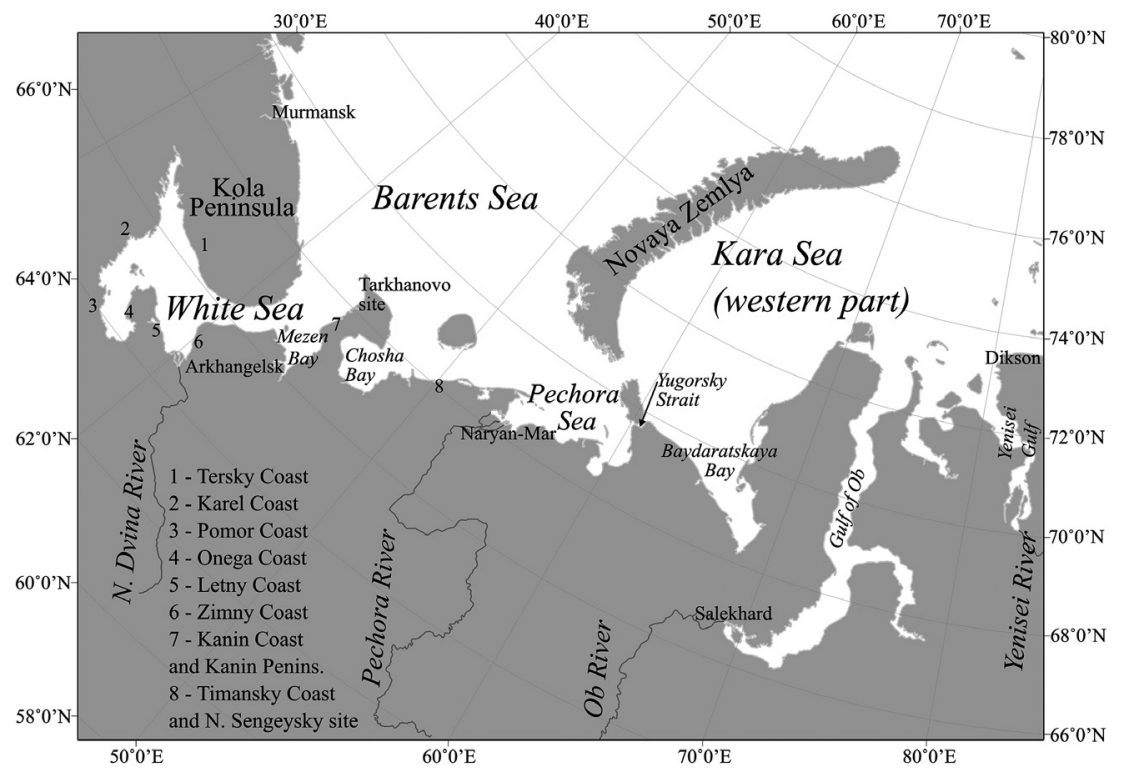

Fig. 1. Map of the study area and major toponyms used in the text.

So far, we know little about the sources of long-term beluga whaling data. It seems important to study and publish quantitative data of beluga catches from the original sources, which are expected to contain the most detailed and reliable information. It can also be assumed that these data were collected in all years of harvesting by the same companies using a uniform technique, and, therefore, an inter-annual comparison of data from these sources would be valid, and not compromised by differences in data collection methods. Moreover, we expect that, in addition to catch numbers, associated information as body size, age, and sex of harvested beluga whales, as well as details of the time and location of commercially valuable aggregations can also be found in the documents of whaling companies. The availability of such annual data could be very useful for the study of biology, population dynamics, and population structure of the beluga whale.

To date, the population status of the beluga whale in the White, Barents, and Kara seas is not fully clarified. Most researchers currently consider the White Sea population as separate (Shpak et al., 2018), whereas the structure of the beluga population in the Barents and Kara seas remains unstudied. Genetic data analysis confirmed isolation of the White Sea beluga whales from animals inhabiting the waters of Svalbard archipelago (Meschersky et al., 2018). If we recognize the presence of a distinct population in the White Sea, then it makes sense to analyze the catches in this area separately. At most whaling sites of the White Sea, harvesting was irregular, and, therefore, the data from them are scarce. Long-term catch series (1950-1984) are available for only one whaling site, Tarkhanovo (Ognetov, 1987: 122), located at the geographical border of the White Sea and the Barents Sea (Fig. 1). The boundary position of this site and lack of information on exact catch locations makes it impossible to unambiguously assign caught whales to the White Sea population.

In the 20th century, both coastal (everywhere) and ship-based beluga hunting was conducted in the study areas. Offshore hunting was widespread mainly in the Barents Sea and in the southwestern Kara Sea. Beluga whales were hunted from shore in summer, and from vessels - throughout the ice-free period, until November (RGAE ${ }^{1}$, f.9256, inv.2, c.669, sh.97). When considering harvests in the Barents and Kara seas, it should be taken into account that animals from the White Sea population could also be present in catches, because it cannot be completely ruled out that a part of belugas could leave the White Sea and visit, for example, the Chosha Bay and, in the autumn-winter period, other waters of the Barents Sea.

\section{History of beluga harvesting before the 1930s}

The archaeological finds (remains of bones, petroglyphs) indicate that beluga whales have been hunted in the White and Barents seas since the $3^{\text {rd }}-1^{\text {st }}$ millennium $\mathrm{BC}$; in the Kara Sea, since the $1^{\text {st }}$ millennium BC (Krupnik, 1989; Savateev, 1991). Documentary evidence of the existence of this kind of harvest are dated back to the $16^{\text {th }}$ century for the White Sea (The account..., 2013), $17^{\text {th }}$ century for the Barents Sea ${ }^{2}$, and $19^{\text {th }}$ century for the Kara Sea (Notes..., 1824).

Before the 1930s, the major sites of beluga hunt in the White Sea were the Mezen' Bay and Severnaya Dvina estuary. In the Barents Sea, those were the Chosha Bay

\footnotetext{
${ }^{1}$ Russian State Archive of Economics (Rossiyskiy Gosudarstvenniy Arkhiv Ekonomiki, f. - fund (фонд), inv. - inventory (опись), с. -case (дело), sh. - sheet (лист)).

${ }^{2}$ Karmakulov Bay (Novaya Zemlya) was mentioned as a site for harvesting beluga whales in the 17th century (1682) (Belov, 1956).
} 


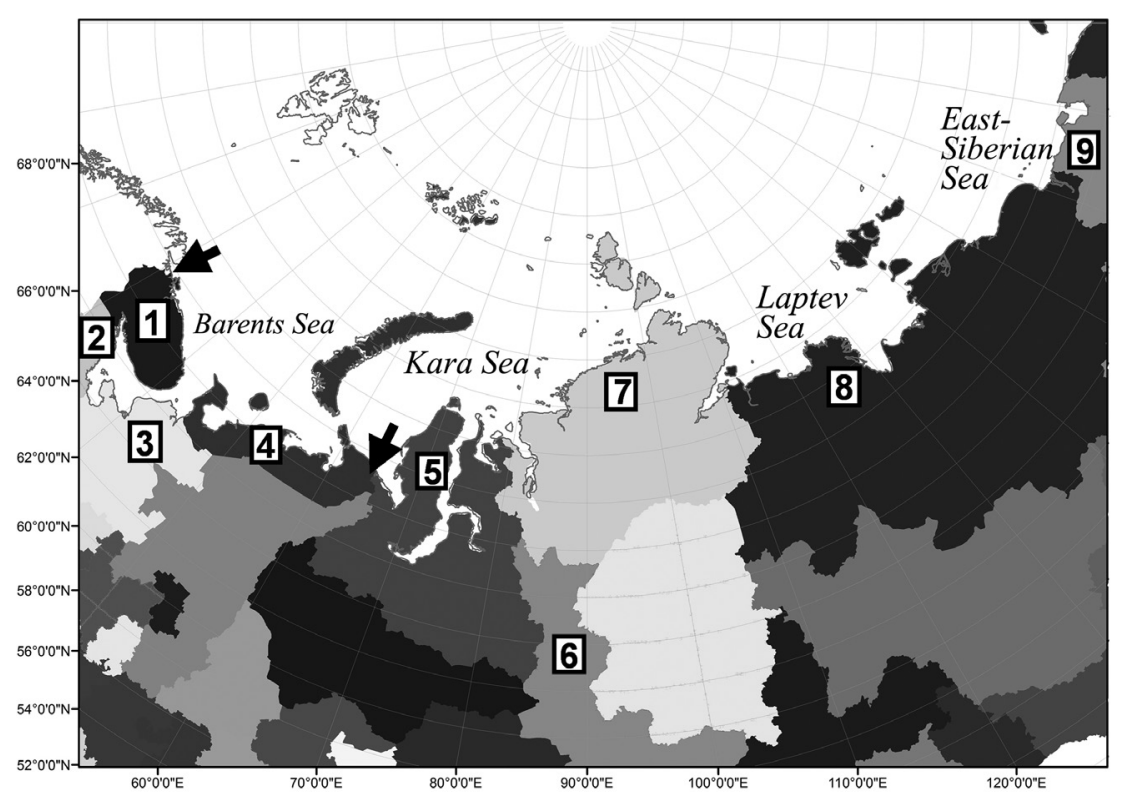

Fig. 2. Administrative regions, where archives are located: 1 - Murmansk Oblast, 2 -Republic of Karelia, 3 - Arkhangelsk Oblast, 4 - Nenets Autonomous Okrug (NAO), 5 - Yamalo-Nenets Autonomous Okrug (YaNAO), 6 - Krasnoyarsk Krai, 7 - Taimyr Okrug, 8 - Republic of Sakha (Yakutia), 9 - Chukotka Autonomous Okrug. Black arrows mark the coastal borders of the Northern Fishery Basin.

and waters off Novaya Zemlya and Svalbard (Studies..., 1862; Webermann, 1914: 145; On fisheries..., 1923). To catch belugas, hunters supposedly used animals' near-shore feeding grounds. Harvest in the Kara Sea was probably very small in size. The available sources mention the hunting sites in the Gulf of $\mathrm{Ob}$, Baydaratskaya Bay, and Yenisei Gulf (Notes ..., 1824; Finsch \& Bram, 1882; Latkin, 1892).

The main catching gear used in the White Sea and in the Chosha Bay was a kind of surrounding net. In Novaya Zemlya, whales were landed mainly by blocking a narrow shallow-water inlet after beluga occasionally entered it (Zhitkov \& Buturlin, 1901: 143; Borisov, 1926). In the Kara Sea, single animals were hunted with a spear; in the Gulf of Ob, using a blockage with stakes and a seine. Attempts to organize regular whaling in the Kara Sea using a special beluga seine were undertaken periodically, but they all failed mainly because of the difficulties associated with selling products (Notes..., 1824; Borisov, 1907).

Quantitative data on whaling from the $16^{\text {th }}$ to the mid $-19^{\text {th }}$ centuries are quite fragmentary. In the second half of the $19^{\text {th }}$ century, the Arkhangelsk Guberniya Statistical Committee annually published statistics on catches of all commercial species. The harvest data of beluga whales show the instability of catches and the irregularity of whaling campaigns. In certain years, no operations were conducted at some of the whaling sites (Reports..., 1875-1916).

The catch per year in the White Sea from 1782 to 1914 constituted from 12 to 377 animals; the total catch for the White and Barents Seas, from 15 to 1200 animals, with zero catches for some years (Reports..., 1875-1916;
The memorial..., 1912; Webermann, 1914: 55; RGAE, f.1, inv.2, vol.1a, c.190a, sh.7).

The significant variations in catches and irregularity of whaling operations were caused by several factors. First, beluga seine was the most expensive of fishing gears in the North of Russia. In the late $19^{\text {th }}$ to early $20^{\text {th }}$ centuries, a beluga seine cost 2000-3000 rubles, while the annual income of a hunter was no more than 300 rubles. Usually, such a seine belonged to all residents of one or several Pomor settlements or, otherwise, was rented, and the ability to purchase or fix a beluga seine depended on some socio-economic factors (Webermann, 1914: 151; Krechkov, 1924; Rostislavin, 1926: 17, 102). Second, the catching technique was complicated, and a mistake of one of the members of a hunting team could cause the entire group of animals to escape from the closed trap of seine (Zhitkov, 1922). Also, whaling operations could only be conducted in an artel (a hunting team); as a rule, no fewer than 11 boats with 3-4 hunters in each were used in them ${ }^{3}$. Since whaling was exclusively coastal, it depended on groups of animals approaching the shore. However, in spite of the high cost, complexity, and uncertainty of whaling results, artels continued to hunt belugas, because in the case of successful catch the profits were significant (AGV, 1877; $\mathrm{GAAO}^{4}$, f.1, inv.8, c.1456, sh.51; GAAO, f.549, inv.1, c.151). Until the early $20^{\text {th }}$ century, an important sales

\footnotetext{
${ }^{3}$ In the Arkhangelsk Guberniya Statistical Committee Report for 1881, only eight persons were mentioned for the Zolotitskaya Volost administrative region, who hunted beluga whales. It can be assumed that those hunters joined the teams from other regions. To catch beluga whales using a purse seine, eight people did not seem enough.

${ }^{4}$ State Archive of Arkhangelsk Oblast [Gosudarstvenniy Arkhiv Arkhangelskoy Oblasti].
} 
Y.I. Alekseeva et al.

\begin{tabular}{|c|c|c|c|c|c|c|c|c|c|c|}
\hline 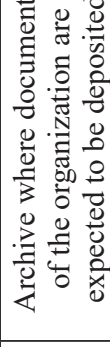 & 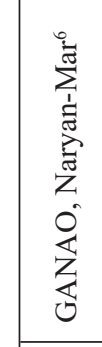 & 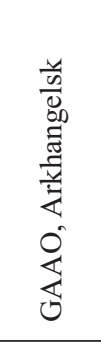 & 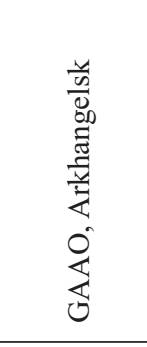 & 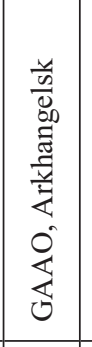 & 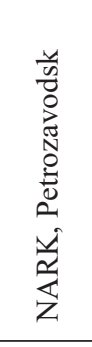 & 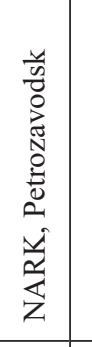 & 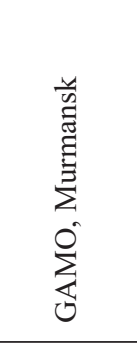 & 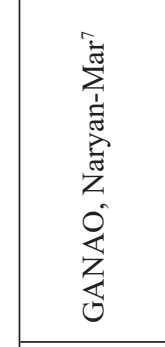 & 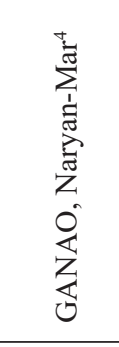 & 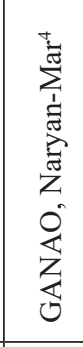 \\
\hline 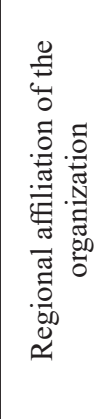 & 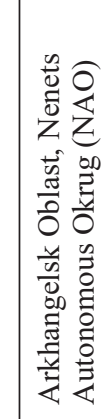 & 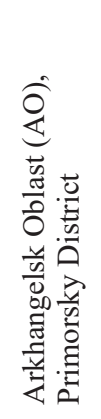 & 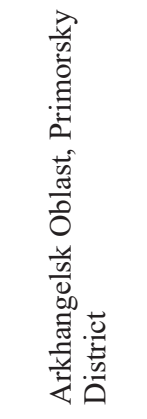 & 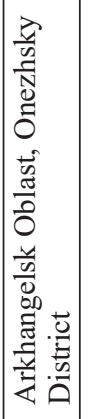 & 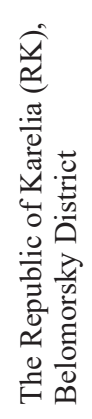 & 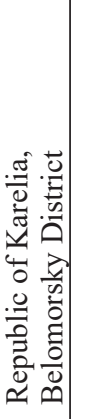 & 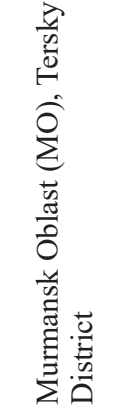 & 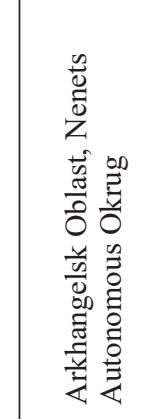 & 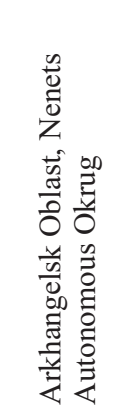 & 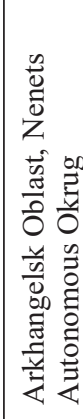 \\
\hline 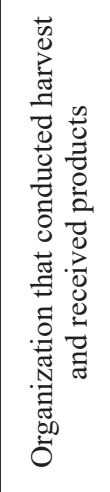 & 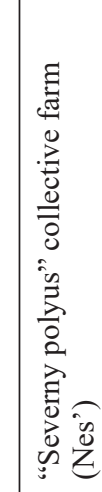 & 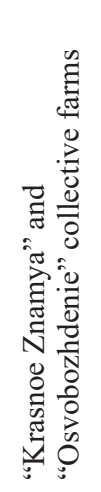 & 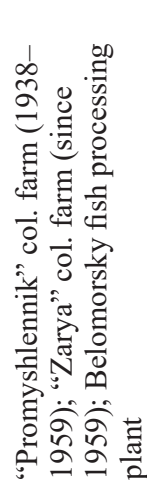 & 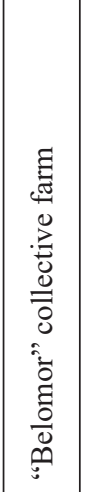 & a. & 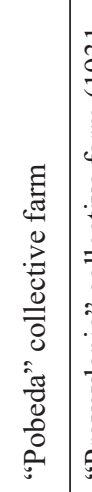 & 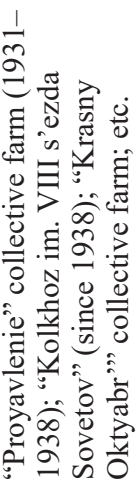 & 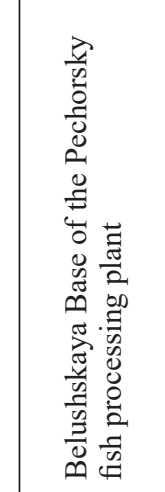 & 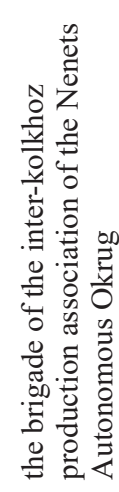 & a. \\
\hline 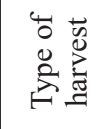 & 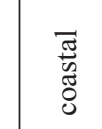 & 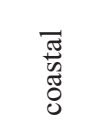 & 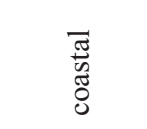 & 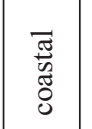 & $\begin{array}{l}\text { 嵒 } \\
\text { 总 }\end{array}$ & $\begin{array}{l}\text { 急 } \\
\text { 总 }\end{array}$ & $\begin{array}{l}\text { 嵒 } \\
\text { 总 }\end{array}$ & $\begin{array}{l}\text { 隐 } \\
\text { 㺃 }\end{array}$ & 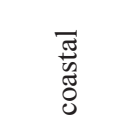 & 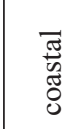 \\
\hline 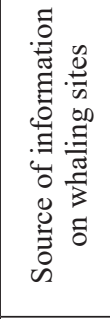 & 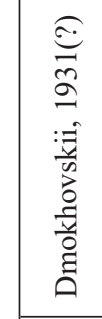 & 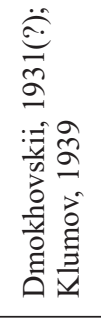 & 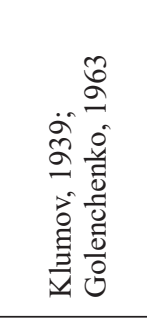 & 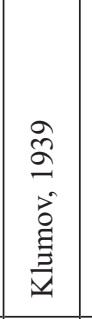 & 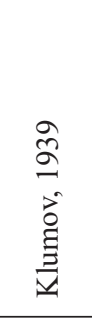 & 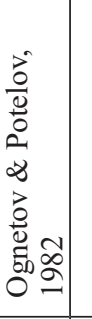 & 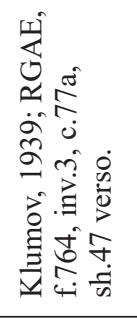 & 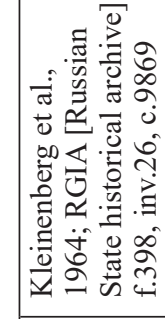 & 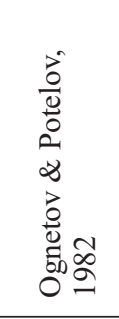 & 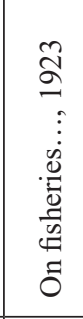 \\
\hline 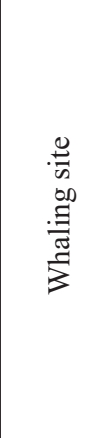 & 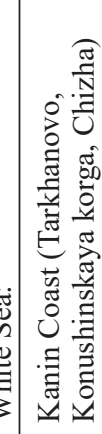 & 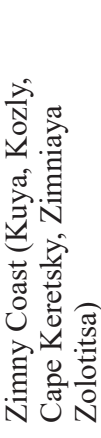 & 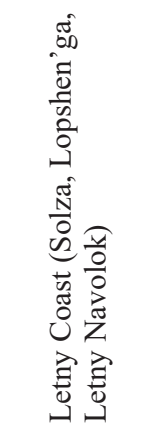 & 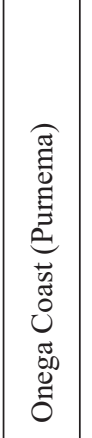 & 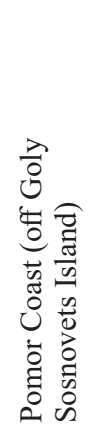 & 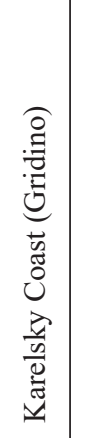 & 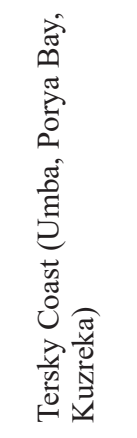 & 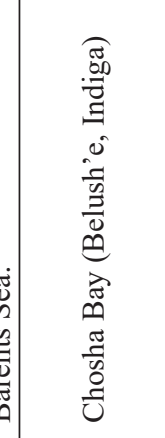 & 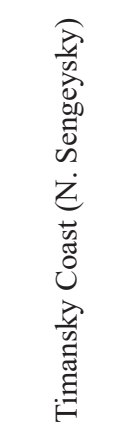 & 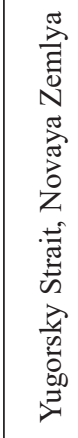 \\
\hline
\end{tabular}




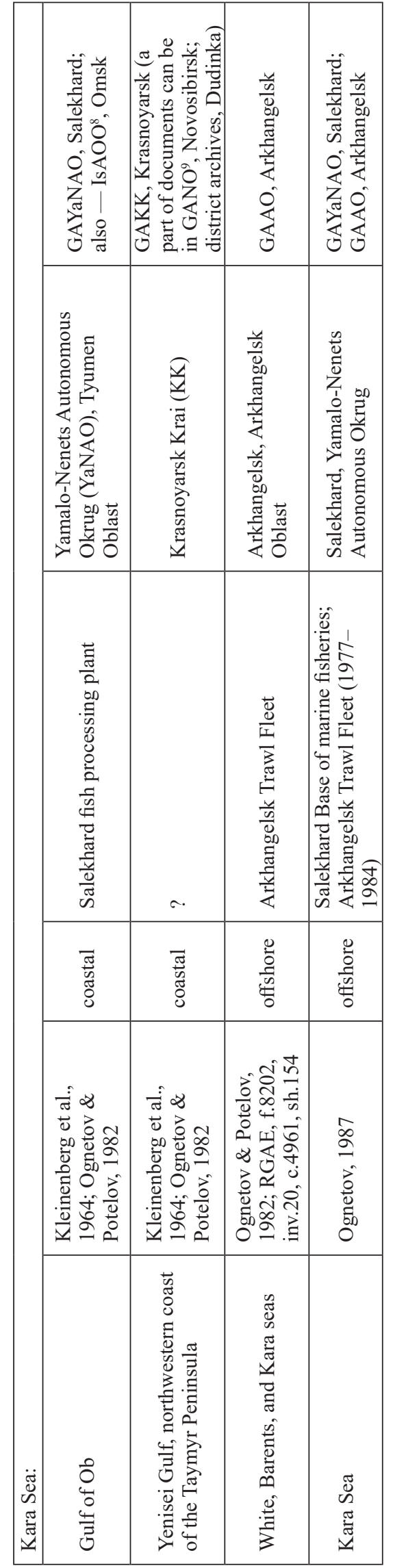

product was the rendered blubber (or whale oil) used in the regions of the Russian European North mainly for lighting. A major part of whale oil produced in Arkhangelsk was exported (Acts..., 1988; AGV, 1857, 1879; A historical..., 1881; Report..., 1876; SGIAPMZ ${ }^{5}$, f.2, inv.1, c.76, P.5). Belugas skin was rarely used, as there was no practice of processing it (AGV, 1857).

In the $1920 \mathrm{~s}$, after the World War I and the Revolution, the traditional fishery activities in the North of Russia were restored, and new forms of management of marine resources, which included belugas, such as collective farms (kolkhoz) and state-owned enterprises, had appeared. At that time, organizations for managing the fisheries and buying up catches were forming. These new organizations produced detailed reports of catches, which have not being looked or referenced in details since.

The goal of our work was to find and analyze archival documents containing quantitative and qualitative information on harvests of beluga whales after the 1920s, when whaling collective farms and state enterprises appeared, and new organizations responsible for whaling and its management formed. In addition, in the process of work, we expected to evaluate the possibilities and potential for this kind of research in the archives of the Russian Federation.

\section{Material and Methods}

The most promising sources for the study of data on whaling in the White, Barents, and Kara seas are the annual reports from the companies that directly conducted it, i.e. the collective farms and the Arkhangelsk Trawl Fleet. They could provide the most detailed information about the progress and sites of whaling, quantitative data on harvests, and, possibly, biological characteristics of the animals caught.

The original documents from the organizations that harvested belugas or regulated it are currently deposited in regional (Fig. 2) archives. Coastal whaling was conducted mainly by local companies, which could easily be identified if whaling sites were known. The information on the catch areas is sufficiently represented in the scientific literature and some archival sources. The organizations that used one of the whaling sites changed over the study period, but, as a rule, remained within the same administrative unit, and their documentation is stored in the same archive. The preparatory stage of our work consisted of identification of the main whaling sites in the study area from the 1930s and the fishery organizations that conducted whaling. The sites of coastal and offshore whaling in the 20th century and information on the leading fishery companies, as well as corresponding archives, are listed in Table 1.

One could see from the Table 1 the archival search should be carried out in at least six cities (Murmansk,

${ }^{5}$ Solovetsky State historical-architectural and nature museum-reserve [Solovetskiy gosudastvenniy istoriko-arkhitekturniy i prirodniy muzey-zapovednik]. 
Table. 2. Beluga whale catches (number of individuals/weight of raw material, hundred kilograms ${ }^{10}$ ) by coastal and offshore harvest in the Northern Fisheries Basin found in the documents of Sevryba (1933-1948) and Sevrybvod (1943-1987), RGAE. Presumably incomplete data are highlighted in italics; our summation, in bold. Dash sign (“"-): figure is absent in the document.

\begin{tabular}{|c|c|c|c|c|c|}
\hline Year & $\begin{array}{c}\text { White Sea, } \\
\text { coastal } \\
\text { harvest }\end{array}$ & $\begin{array}{l}\text { Barents } \\
\text { Sea, coastal } \\
\text { harvest }\end{array}$ & $\begin{array}{l}\text { Barents and } \\
\text { Kara seas } \\
\text { (offshore } \\
\text { harvest) }\end{array}$ & $\begin{array}{l}\text { White, Barents, } \\
\text { and Kara seas } \\
\text { (total catch in the } \\
\text { Northern Basin) }\end{array}$ & RGAE, source \\
\hline 1933 & & & & $734 / 1770$ & f. 8202 , inv.22, c. 28, sh.46 \\
\hline 1934 & & & & $356 / 853^{11}$ & f. 8202, inv. 22, c. 28, sh. 45 \\
\hline 1935 & & & & $183 / 379$ & f. 8202 , inv. 22, c. 28, sh. 45 \\
\hline 1936 & & & & $411 / 1615$ & f. 8202, inv. 22, c. 28, sh. 45 \\
\hline 1937 & & & & $-/ 6260$ & f. 8202 , inv. 22, c. 28, sh. 45 \\
\hline 1938 & & & & $-/ 5650$ & f. 8202, inv. 22, c. 28, sh. 45 \\
\hline 1939 & & & & $423 / 981$ & f. 8202 , inv. 22, c. 28, sh. $32,46-47$ \\
\hline 1940 & & & & $497 / 1175$ & f. 8202 , inv. 22, c. 28, sh. $32,46-47$ \\
\hline 1941 & \multicolumn{5}{|c|}{ Sources were not found } \\
\hline 1942 & $90 /-$ & & & & f. 8202, inv. 22, c. 28, sh. 31 \\
\hline 1943 & $56 / 94$ & & & & f. 8202 , inv. 22, c. 28, sh. 31 \\
\hline 1944 & $352 / 594$ & no data ${ }^{12}$ & & & f. 8202 , inv. 22, c. 28, sh. 31 \\
\hline 1945 & $66 / 277$ & no data & & & f. 8202, inv. 22, c. 28, sh. 31 \\
\hline 1946 & & & & $279 / 97$ & f.9256, inv.1, c. 1089, sh.63 \\
\hline 1947 & $3 / 22$ & & & $16 / 0.9$ & $\begin{array}{l}\text { f.8202, inv. } 22 \text {, c. } 28 \text {, sh.26; f.9256, } \\
\text { inv. } 1 \text {, c. } 1089 \text {, sh.63 }\end{array}$ \\
\hline 1948 & & & & $712 / 232$ & f. 8202, inv. 22, c. 28, sh. 26 \\
\hline 1949 & & & & $37 / 92$ & f. 9256 , inv. 1, c. 586, sh. 55 \\
\hline 1950 & \multicolumn{5}{|c|}{ Sources were not found } \\
\hline 1951 & \multicolumn{5}{|c|}{ Sources were not found } \\
\hline 1952 & \multicolumn{5}{|c|}{ Sources were not found } \\
\hline 1953 & & & $23 / 46^{13}$ & & $\begin{array}{c}\text { f.9256, inv.1, c.773, sh.30; f.9256, } \\
\text { Inv.2, c. } 213 \text {, sh.130-131 }\end{array}$ \\
\hline 1954 & & & $290 / 694$ & & f.9256, inv.2, c. 213, sh.130-131 \\
\hline 1955 & & & $139 / 556$ & & f.9256, inv.2, c.213, sh.130-131 \\
\hline 1956 & & & $484 / 1700$ & & f.9256, inv.2, c. 213, sh.130-131 \\
\hline 1957 & & & $477 / 1915$ & & f.9256, inv.2, c. 213, sh.130-131 \\
\hline 1958 & & & $718 / 2247$ & & f. 9256 , inv. 2, c. 213 , sh. $130-131$ \\
\hline 1959 & 374 & & $127 /-$ & $501 /-$ & f.9256, inv.2, c. 212, sh. 156 \\
\hline 1960 & & & $2690 /-^{14}$ & & f.9256, inv.2, c. 271 , sh.197 \\
\hline 1961 & & & $1723 /-$ & & f. 9256 , inv. 2, c. 335, sh.53 \\
\hline 1962 & & & $1125 /-$ & & f. 9256 , inv. 2, c. 30, sh. 37 \\
\hline 1963 & & & $1030 /-$ & & f. 9256 , inv. 2 , c. 792, sh. 50 \\
\hline 1964 & & & $3441 /-$ & $5961 /-$ & f. 9256 , inv. 2, c. 554, sh.56 \\
\hline 1965 & $68 /-$ & $53 /-$ & $1684 / 6428^{9}$ & $1751 /-$ & f. 9256 , inv. 2, c. 669, sh. $97-98$ \\
\hline 1966 & \multicolumn{5}{|c|}{ Sources were not found } \\
\hline 1967 & 208 & 9 & & & f.8202, inv.20, c.2934, sh.85 \\
\hline 1968 & 0 & 22 & & & f. 8202, inv. 20, c. 2934, sh. 85 \\
\hline
\end{tabular}

\footnotetext{
${ }^{10}$ Most documents do not specify if this is the total weight or weight of the parts taken for processing, i.e. meat and/or blubber.

${ }^{11}$ Data for 1934, 1935, 1939, and 1940 (in italics) are probably incomplete, as only data of "buy-up" by procurement offices (i.e., the catches by collective farms) are provided in the document; in the column of "state harvest" data, there is a dash, unlike for 1936-1938, when the catches by both collective farms and state enterprises were indicated.

${ }^{12}$ For 1944 and 1945, it is indicated that data on the Chosha-Pechora Trust are missing. Presented are the data on the White Sea Trust, which apparently covered the entire fishery area in the White Sea.

${ }^{13}$ Data for 1953-1958 are provided in the source in one table with the note "according to incomplete data". We put these values in the column "offshore whaling", as it is known that in 1953 belugas were caught during a walrus harvest, which was carried out using four motorized schooners in the waters of the Franz Josef Land, Novaya Zemlya, and the Laptev Sea (RGAE, f.9256, inv.1, c.773, sh.30), and also because similar values are indicated for offshore whaling in 1953-1957 by Maminov (1959).

${ }^{14}$ In the document, in the table of catches, there is a dash in the column "White Sea"; this figure is given in the column "Barents Sea". We assume that the catch refers to the offshore whaling.

${ }^{15}$ Total weight (including the weight of the blubber -3328 , meat -3100 hundred $\mathrm{kg}$ ).
} 


\begin{tabular}{|c|c|c|c|c|}
\hline 1969 & 0 & $134 /-$ & $134 /-$ & f.8202, inv. 20 , c. 3929 , sh. 136 \\
\hline 1970 & $832 /-$ & 0 & $832 /-$ & f.8202, inv. 20, c. 3929, sh. 136 \\
\hline 1971 & $461 /-$ & 0 & $461 /-$ & f.8202, inv.20, c.3929, sh.136 \\
\hline 1972 & $436 /-$ & 0 & $476 /-$ & f. 8202 , inv. 20, c. 3929 , sh. 136 \\
\hline 1973 & $159 /-$ & $40 /-$ & $199 /-$ & f.8202, inv. 20, c. 3929 , sh. 136 \\
\hline 1974 & $137 / 615$ & $9 / 36$ & $146 / 651$ & f. 8202 , inv. 20, c. 8448, sh. 84 \\
\hline 1975 & 91/- & $0 /-$ & 91 & f. 8202 , inv. 20, c. 8448 , sh. 84 \\
\hline 1976 & $274 / 660$ & $38 / 95$ & $312 / 755$ & f.8202, inv.20, c. 8448 , sh. 84 \\
\hline 1977 & $215 / 672$ & $457 / 1570$ & $672 / 2242$ & f.8202, inv.20, c.8448, sh.84 \\
\hline 1978 & 0 & 0 & $\mathbf{0}$ & f.8202, inv.20, c. 8448 , sh. 84 \\
\hline 1979 & $121 /-$ & 0 & 121 & f. 8202 , inv. 20 , c. 8448 , sh. 84 \\
\hline 1980 & $28 / 80$ & $60 / 895$ & 88/975 & f.8202, inv.20, c. 8448 , sh. 84 \\
\hline 1981 & $170 /-$ & 0 & 170 & f. 8202 , inv. 20, c. 8448 , sh. 84 \\
\hline 1982 & $1 / 2$ & 0 & $1 / 2$ & f. 8202 , inv. 20 , c. 8448 , sh. 84 \\
\hline 1983 & $27 / 83$ & $144 / 1130$ & 171/1213 & f.8202, inv.23, c.981, sh.109 \\
\hline 1984 & $39 / 190$ & $300 / 180$ & $339 / 370$ & f.8202, inv.23, c.981, sh.109 \\
\hline 1985 & $110 / 590$ & $43 / 164$ & $153 / 754$ & f.8202, inv.23, c. 981 , sh.109 \\
\hline 1986 & $172 /-$ & 0 & 172 & f.8202, inv.23, c.981, sh.109 \\
\hline 1987 & $9 /-$ & 0 & 9 & f.8202, inv.23, c. 981 , sh.107 \\
\hline
\end{tabular}

Table 3. Offshore beluga whale catches in the Northern Fisheries Basin found in the documents of the Arkhangelsk Directorate of the Fishing Industry, 1953-1963 (GAAO, f.5833, inv.2, c.543, sh.223)

\begin{tabular}{|c|c|c|c|c|c|c|}
\hline Year & $\begin{array}{c}\text { Number of } \\
\text { schooners }\end{array}$ & $\begin{array}{c}\text { Number of } \\
\text { hunters }\end{array}$ & $\begin{array}{c}\text { Number of } \\
\text { animals }\end{array}$ & $\begin{array}{c}\text { Weight, } \\
\text { hundred kg }\end{array}$ & $\begin{array}{c}\text { Blubber, } \\
\text { hundred kg }\end{array}$ & $\begin{array}{c}\text { Meat, hundred } \\
\mathrm{kg}\end{array}$ \\
\hline 1953 & 2 & 46 & 21 & 104 & 46 & 58 \\
\hline 1954 & 4 & 92 & 290 & 1438 & 56 \\
\hline 1955 & 5 & 115 & 139 & 556 & 313 \\
\hline 1956 & 2 & 253 & 488 & 1816 & 858 \\
\hline 1957 & 7 & 161 & 455 & 1462 & 712 \\
\hline 1958 & 2 & 253 & 2212 & 5503 & 2500 \\
\hline 1959 & 9 & 207 & 2164 & 6887 & 3303 \\
\hline 1960 & 9 & 207 & 2331 & 9250 & 3003 \\
\hline 1961 & 9 & 207 & 1181 & 6389 & 3584 \\
\hline 1962 & 9 & 207 & 1143 & 6577 & 3154 \\
\hline 1963 & 10 & 230 & 960 & 4156 & 3446 \\
\hline
\end{tabular}

Petrozavodsk, Arkhangelsk, Naryan-Mar, Salekhard, and Krasnoyarsk).

An attempt was made to obtain the information by sending inquiries to several archives. In most cases, archives do not have human resources, and documents could be obtained only while personal visit of the archive. We didn't send the inquiry to the State Archive of Arkhangelsk Oblast (GAAO) at this time, because the request would be processed during the following year. The State Archive of the Yamalo-Nenets Autonomous Okrug (GAYaNAO, Salekhard) provided information on the offshore harvests of beluga whales in 1963. The State Archive of the Nenets Autonomous Okrug (GANAO, Naryan-Mar) performed a large amount of work on our inquiry: viewed the summarized annual reports for 1945-1990 and provided data on beluga whale catches in the years for which information was available (1970 1990). Since it was not possible to obtain data from all the archives by inquiry, and because we, in addition to catch statistics, were interested in information relevant to the beluga biology, we decided to compile only uniform information, which we personally found in the archives.
The process of finding the original documents was as follows. All fishery organizations annually submitted reports to the regional offices of the Fishing Industry Directorate (Upravlenie Rybnoy Promyshlennostyu), which, in turn, sent annual reports to the central office. These reports and some other documents on fisheries are stored in the Russian State Archive of the Economics (RGAE) in Moscow. Reports submitted to the central office contain fewer details than the local reports, but, on the other hand, these documents provide summary information on catches for each fishery basin. The harvests of beluga whales in the White, Barents and western Kara seas were assigned to the Northern Fishery Basin; in the Kara and the Laptev seas, to the Siberian Fishery Basin (Fig. 2). Since there are many documents for each basin, it was decided to study first the data on the Northern Basin, where catches were higher. The Northern Basin includes the White, Barents, and western Kara seas within Arkhangelsk Oblast, which was formed in 1937.

In addition, some information on offshore harvest of beluga whales was collected in GAAO, Arkhangelsk. 
Table 4. Beluga whale coastal catches found in the documents of the Chosha-Pechora fishermen's collective farm union, 1970-1990 (GANAO, f.170, inv.1)

\begin{tabular}{|c|c|c|}
\hline Year & Number of whales taken & Source \\
\hline 1970 & 820 & c. 612, sh.59 \\
\hline 1971 & 456 & c. 619, sh.31 \\
\hline 1972 & 433 & c. 632, sh. 6 \\
\hline 1973 & 199 & c. 639 , sh.9 \\
\hline 1974 & 144 & c. 646, sh. 9 \\
\hline 1975 & 92 & c.653a, sh.8 \\
\hline 1976 & 301 & c. 663, sh. 20 \\
\hline 1977 & 228 & c. 672, sh. 10 \\
\hline 1978 & No data & c. 681 \\
\hline 1979 & 123 & c. 692, sh. 46 \\
\hline 1980 & 28 (with one fixed net at the Tarkhanovo site) & c. 705, sh. 16 \\
\hline 1081 & 169 & c. 722, sh. 10 \\
\hline 1982 & No data & c. 739, sh.19 \\
\hline 1983 & 27 & c. 753, sh. 10 \\
\hline 1984 & 39 & c. 765 , sh. 110 \\
\hline 1985 & 107 & c. 779, sh. 29 \\
\hline 1986 & 172 & c. 797, sh.34 \\
\hline 1987 & 9 & c. 819, sh.16 \\
\hline 1988 & No data & c. 832, sh. 833 \\
\hline 1989 & No data & c. 838 \\
\hline 1990 & No data & c. 843 \\
\hline
\end{tabular}

Table 5. Beluga whale catches (number of individuals/weight of raw material, hundred kilogram) in Siberian Basin found in the documents of the Ob-Irtysh and Krasnoyarsk basin directorates for fisheries, 1933-1949. For certain years, total catches for the Northern and Siberian basins are also provided (RGAE, f.8202, inv.22, c.28).

Dash sign (“-"): figure is absent in the document.

\begin{tabular}{|c|c|c|c|c|}
\hline \multirow{2}{*}{ Year } & \multicolumn{3}{|c|}{ Kara Sea } & \multirow{2}{*}{$\begin{array}{c}\text { Northern and Siberian } \\
\text { basins (White, Barents, } \\
\text { and Kara seas, total) }\end{array}$} \\
\cline { 2 - 4 } & Siberian Basin ${ }^{10}$ & $\begin{array}{c}\text { Territory of YaNAO } \\
\text { (Siberian Basin) }\end{array}$ & $\begin{array}{c}\text { Territory of } \\
\text { Krasnoyarsk Krai } \\
\text { (Siberian Basin) }\end{array}$ & \\
\hline 1933 & $837 / 1960$ & & & $1571 / 3730$ \\
\hline 1934 & & $378 / 971$ & \\
\hline 1935 & & $201 / 764$ & & \\
\hline 1936 & & $464 / 1807$ & & \\
\hline 1937 & & $519 / 291$ & & \\
\hline 1938 & $12 / 46$ & $118 / 548$ & & \\
\hline 1939 & $283 / 1206$ & & & \\
\hline 1940 & $210 / 810$ & & & \\
\hline 1942 & $235 / 1175$ & & & \\
\hline 1943 & & & & \\
\hline 1944 & $648 / 1490$ & & & \\
\hline 1948 & & & & \\
\hline 1949 & & $54 / 150$ & & \\
\hline
\end{tabular}

In addition to results of our search, we will separately present the data from the summary reports provided by the GANAO archive, Naryan-Mar. That will allow us to see if there are discrepancies in different reports (RGAE vs. GANAO and GAAO) on harvests in the same area.

\section{Results}

In RGAE, we studied a total of 93 reports of the Fishing Industry Directorate for the Northern Basin (Sevryba), Arkhangelsk Northern Basin Directorate for 
Conservation and Recovery of Fishery Resources (Sevrybvod), the Karelia Basin Directorate (Karelrybvod), Murman Basin Directorate (Murmanrybvod), and the Northern and Chosha-Pechora fishing collective farms and fishermen's collective farm unions (1935-1988).

Annual data on the size of beluga catches were found in documents of Sevryba (1933-1948) and Sevrybvod (1943-1987) (Table 2). Sevryba was responsible for the entire Northern Basin (Fig. 2). The territory subordinate to Sevrybvod was as follows: from the Karelian Autonomous Soviet Socialist Republic (KASSR) to the east along the White Sea coast to the Kanin Peninsula, the southeastern Barents Sea and the southwestern Kara Sea. The northwestern Barents Sea and the Tersky Coast of the White Sea were supervised by Murmanrybvod; the Pomor and Karel coasts of the White Sea, by Karelrybvod. In the reports of these organizations for certain years $(1956,1960,1963,1965,1975$, and 1980), no information on catches was found; for some years, data on harvests of "morzver", a collective term for harvested marine mammals, mostly seals, but also small cetaceans, were provided. This is most likely due to the small-scale and, apparently, irregular harvesting of beluga whales, conducted here throughout the 20th century.

Most of Sevryba's reporting documents also do not provide marine mammal catches by species; the information in them is given under the general heading "morzver". The explanation for the lack of detailed information was the fact that Sevryba and the collective farms were aimed primarily at catching fish. The main commercially valuable marine mammal species in the Northern Basin was the harp seal (Pagophilus groenlandicus Erxleben, 1777). The proportion of the other marine mammals in catches was negligible. In 1934, among the products of harvested marine mammals, bought by the district procurement offices of Sevgostrest, harp seals accounted for $97.63 \%$ of catches; ringed seals (Phoca hispida Schreber, 1775 ) - 1.71\%; bearded seals (Erignathus barbatus Erxleben, 1777) - 0.15\%; and beluga whales - $0.51 \%$ (RGAE, f.1877, inv.1, c.286, sh.10). This proportion on marine mammal catches must have remained similar in the following years. In 1980, the fishery plan was fulfilled by $97.3 \%$ in terms of the number of animals and by $94.6 \%$ in terms of the amount of fat (blubber). The catch was almost entirely represented by the harp seals $(38520$ animals). It was reported that the missing percentage of the complete plan in that year was caused by the lack of beluga and spotted seal catches due to the "poor harvest situation" (RGAE, f.8202, inv.20, c.7252, sh.26).

A separate document from the Arkhangelsk Directorate of the Fishing Industry, containing detailed information on offshore harvests of beluga whales in the Northern Fisheries Basin in 1953-1963, was found in GAAO (Table 3 ). The harvest seasons described in this document coincided with those described in the archive documents from RGAE (Table 2, offshore harvest). We decided to present both sources in order to illustrate the differences in catch reports.

Another set of data, which may also be compared to the data found in RGAE (Table 2, coastal harvest in the
White and Barents seas), is the compilation prepared for us by the staff of the GANAO. They have viewed the summary documents of the archival fund of the Chosha-Pechora fishermen's collective farm union of the NAO of Arkhangelsk Oblast for 1945-1990. The first information on beluga whaling in this Okrug was found in the documents of 1962, and it became possible to find information on the catches for most years in the period 1970-1990 (Table 4). No data on whaling sites for certain years are provided in the information letter from the NAO archive, but it is likely that whaling was conducted from coast mostly at the Tarkhanovo whaling site (White Sea), in the Chosha Bay and at the N. Sengeysky site (Barents Sea). These sites are indicated in the documents from RGAE (RGAE, f.8202, inv.20, c.3929, sh.136).

In addition to documents on the beluga whale catches in the Northern Fisheries Basin, the reports on catches in Siberian Basin (Kara Sea, Ob-Irtysh and Krasnoyarsk basin directorates for fisheries) for certain years have also been found in RGAE (Table 5). To date, we could not find annual reports containing data of beluga whaling in these areas. In the reports of the fisheries directorates, which supervised harvesting of marine mammals in most of the Kara Sea, for the late 1950 s to the $1960 \mathrm{~s}$, and also in the information letter from the YaNAO Archive, only data on "morzver" harvests are provided without indication of marine mammal species. The numbers of "morzver" taken by the Tyumen Sovnarkhoz in 1947-1958 varied from 17 to 1267 individuals; in 1960, it reached 1814 individuals; and in 1961 and 1962, 7071 and 7362 individuals, respectively (RGAE, f.9256, inv.2, c.772, sh.37). In documents of Sevrybvod from 1960s, the beluga whale is indicated as the key commercial species among the marine mammals of the Kara Sea (RGAE, f.8202, inv.20, c.940, sh.4; RGAE, f.8202, inv.20, c.1462, sh.2; and other). Although we suppose, beluga constituted a large portion of these "morzver" catches, we cannot judge the scale of beluga harvest based solely on available data.

In the document with beluga harvest statistics for Siberian basin (Table 5), total beluga whale catches made by all the fishery organizations of the Northern and Siberian basins in the White, Barents, and Kara seas were also found for four years (Table 5).

\section{Discussion}

\section{Data collection technique}

We have obtained offshore catch data for the same years (1953-1963) from two sources - the Sevrybvod (Table 2) and the Arkhangelsk Directorate of the Fishing Industry (Table 3 ). We have also found coastal catch data for the same years (1970-1987) from two sources - the Sevrybvod (Table 2) and Chosha-Pechora fishermen's collective farm union, which caught the major part of beluga whales (Table 4). There are differences in the data, but mainly the values are similar. The same can be said 
about data of most published papers (Maminov, 1959; Kleinenberg et al., 1964; Ognetov, 1999) when they are compared with original reports, which means that the authors apparently used various sources with sometimes slightly differing data. We cannot assess the difference in the data collection technique used by the Arkhangelsk Directorate of Fishing Industry and Sevrybvod and cannot judge whose data are more reliable. Therefore, when considering long-term data, it makes sense to rely on reports of one of the organizations, assuming that its data were collected by a uniform methodology and, thus, are more comparable within a time series. Furthermore, transfers of the data from one source to another inevitably led to errors. For example, in Sevrybvod's report for 1973 it was stated that 157 belugas were caught at the Tarkhanovo whaling site (northern White Sea), 40 at N. Sengeysky (Barents Sea), and 2 off the Letny Coast of the White Sea. However, according to the summary table of catches in this document, two animals were caught in the White Sea and 197 in the Barents Sea (RGAE, f.8202, inv.20, c.3929, sh.136). Thus, the catch off Tarkhanovo was mistakenly assigned to the Barents Sea basin. This error has migrated from one report to another ever since (RGAE, f.8202, inv.20, c.4961, sh.154; etc.).

To obtain the most reliable and detailed information on total and local catches, the only way is to use data of the organizations that directly conducted whaling (Tables 1,4$)$. In case the opportunity appears to work directly in the regional archives of Salekhard, Krasnoyarsk, etc., it may be possible to find data that would help us single out beluga catches from total "morzver" harvests in the part of the Kara Sea, which belonged to Siberian Basin.

Although the data on the weight of catches are often present in primary reports, it is usually difficult, if not impossible, to analyze them. As mentioned above, blubber was of particular value to industry, but skin, meat and bones were also processed. At different sites, with different processing techniques, and in different economic situations, harvested beluga whales were used in different ways. For this reason, unfortunately, the ratio of the weight of products to the number of slaughtered individuals cannot be used to determine the average weight and, accordingly, the average size and age class of beluga whales. However, sometimes the pair "number of individuals / raw material weight" makes it possible to identify evident errors in documents and remove these figures from further analysis of the data series or mark them as inaccurate numbers. For example, a catch of 60 belugas with a total weight of $89500 \mathrm{~kg}$ is indicated for coastal whaling in the Barents Sea in 1980 (Table 2). Thus, the average weight of product obtained from one beluga constitutes $1492 \mathrm{~kg}$, which exceeds the maximum weight of a male as reported by Lukin and Ognetov (2009) and is close to the maximum body weight for the species $(1600 \mathrm{~kg}$, Jefferson et al., 1993: 77). The records, according to which an average of less than $100 \mathrm{~kg}$ of products was obtained per a slaughtered beluga, also seem doubtful, for example: a total of 300 belugas with an average of $60 \mathrm{~kg}$ products from each (see 1984 in Table 2); and a total of 519 belugas with an average of $56 \mathrm{~kg}$ products from each (1937 in Table 5). Nevertheless, cases with such a low output of products are still possible, as they can be explained by damage/loss of a greater part of the catch due to some circumstances. In general, the possibility to compare the number of harvested individuals to the weight of products obtained serves an additional "reliability indicator".

\section{Discussion on data series}

Ognetov and Potelov (1982) wrote about the uncertainty concerning the beluga whale abundance in the Northern Fisheries Basin and recognized the lack of any reliable estimates. Later, Ognetov (2005) called estimating of the beluga whale population in the White, Barents, and Kara seas "an almost insoluble problem". He suggested using an estimate of 15000 to 18000 individuals based on a mathematical model, but nevertheless indicated that beluga abundance in the first half of the $20^{\text {th }}$ century could have been significantly larger (25000-30000). In the last decade, systematic and uniformly designed abundance surveys were conducted only in the White Sea (Glazov et al., 2010; Solovyev et al., 2012). The minimum summer abundance of the White Sea belugas was estimated to be from 5000 to 7000 individuals for different years. According to the data of 1939, the abundance of beluga whales in the White Sea was 6000-8000, and in the Barents and Kara seas, 25000-50000 animals; suggested catch limit in the White Sea was estimated at 500-700 animals, and in the Barents and Kara seas, 2500-3500 animals (Klumov, 1939: 12, 19-21). In 1971, according to the Northern branch of the Polar Research Institute of Marine Fisheries and Oceanography (SevPINRO), the stocks could sustain a total catch of 600 animals in the White Sea and 3,000 in the Barents and Kara seas (RGAE, f.8202, inv.20, c. 2934 , sh.85); in 1973 , the catch limit was set to 600 animals in the White Sea and 1500-2000 in the Barents and Kara seas (RGAE, f.8202, inv.20, c.3929, sh.136; RGAE, f.8202, inv.20, c.4432, sh.157). During the Soviet period, there was a production plan on each commercial species that was based on the data provided by research and fisheries organizations. In case of non-fulfillment of the plan, the commercial resource was considered "underused", and recommendations were given to increase catch limits. For example, in 1961, according to Sevrybvod's data, the stocks of ringed seals and beluga whales were underexploited, and it was reported that the states of stocks allowed intensification of harvesting (RGAE, f.9256, inv.2, c.335, sh.53).

In the late 1950s and early 1960s, beluga whale harvests were much greater (Table 2) than the recommended limits. Kleinenberg and co-authors (1964: 416) pointed out that harvesting of 3000 individuals in some years in the Northern Basin might adversely affect the reproduction of beluga whales and that restrictions would have to be imposed on whaling in the coming years. Indeed, after the most significant increase in catches in the early $1960 \mathrm{~s}$, the catches significantly decreased after 1966. The largest catch, according to Sevrybvod's data, was 5961 animals in 
1964. This value is much greater than the total catch in the White, Barents and Kara Seas for that year, 2984 individuals, reported in the scientific literature (Ognetov, 1999). It should be taken into account that the figure provided by Sevrybvod refers to the Northern basin only. If in 1964 belugas were also harvested in the central and eastern Kara Sea by fishery organizations of the Siberian Basin, the total catch of belugas inhabiting the White, Barents and Kara Seas may have been even higher. In 1964, a significant part of beluga whales (2520 ind.), according to Sevrybvod's data, were caught by the efforts of coastal whaling, and, therefore, the further decrease in catches apparently cannot be attributed to the termination of offshore whaling only. In the following year, 121 animals were caught by the coastal whaling. Few years later, the coastal catches in 1971-1987 were still low or absent (Table 2). In the 1970s, there was a decrease in the abundance of beluga whales approaching the coasts of the Barents and Kara seas (according to data from interviews, in Ognetov, 1987).

Therefore, it is assumed that the factor responsible for the decrease in catches and abundance of beluga whales in coastal waters was the overharvesting (Boltunov \& Belikov, 2002).

The evidence of overharvesting could be shown in reduction in catch per effort and an increased share of smaller (younger) animals in the population. There are data on the number of vessels involved in whaling operations, but the data on catches per voyage of vessel, which can be regarded as a unit of harvesting effort, are available for only one year, 1965 (RGAE, f.9256, inv.2, c.669, sh.98). At this stage of the study we do not have enough information to judge with certainty the selectivity of whaling in regard to the size of harvested individuals. It can be assumed that large adult animals were a preferred catch. If whaling was conducted selectively, then a rejuvenation of population could have been observed in the long-term series of data in the case of overharvesting, as the average weight of caught individuals would decrease. In our dataset, we could not define a trend in the change of weight in harvested whales. As we have mentioned above, the ratio of the weight of products to the number of harvested animals, according to the documents, varied from $50 \mathrm{~kg}$ to 1.5 tons. Catches in different years could comprise groups of animals of different sex-age compositions. But it is apparent that the "weight" parameter in the summary reports is based on heterogeneous and hence, incomparable information. It is probable that data on size and sex composition, which are important for understanding the harvesting pressure on population, as well as catch per unit effort, could be found in the reports of certain fishery organizations.

In general, the overharvesting was shown by the decrease in coastal catches (although here we also do not have data on catch per unit effort) after years with much higher catches relative to the recommended catch level.

Overharvesting of beluga whales could result in local depletion of certain nursing aggregations, or summer stocks, in some areas. For the study area, such cases have not been described (possibly due to the lack of stationary long-term observations in unpopulated sites of whaling), but in the Tauysky Bay (the Okhotsk Sea), the summer aggregation of beluga whales, which had regularly visited the bay, disappeared right after the intensive hunting in the early 1930s (Solovyev et al., 2015). It is unknown if the stock was used up or it abandoned this summer feeding ground. The philopatry, which is characteristic of beluga whales, could explain why a summer feeding ground remains unoccupied by belugas for a long time after the local stock is extirpated.

The offshore harvesting of beluga whales in the White and Barents seas has been discontinued in 1965 , and hunting schooners were discarded "for unfitness to navigation and hunt" (RGAE, f.8202, inv.20, c.4961, sh.94,154). The beluga whaling in the Kara Sea within the Arkhangelsk Oblast has not been conducted since then. In 1977, 1980, 1983, and 1984, only one hunting vessel operated off Dickson Island, the area which belonged to Siberian basin (Ognetov, 1987: 126). In 1992, commercial whaling in the White, Barents, and Kara seas was ended "for economic reasons" (Boltnev et al., 2016).

Apparently, with a general decline in the size of populations, the irregularity of coastal whaling in the 1970s and 1980s was possibly due to the irregular belugas' visits to the coastal waters and complicated techniques and organization of whaling. These features characterized the beluga whaling throughout its history (Zhilinskii, 1951; GAAO, f.5833, inv.2, c.543, sh.25, 26).

Seasonal distribution of belugas in the Arctic seas is associated with climatic factors, and the extent of ice cover is considered the primary one (Ogentov \& Potelov, 1982: 51; Tynan \& DeMaster, 1997). In addition, it can be assumed that the distribution of beluga whales was substantially influenced by the depression of stocks of polar cod (Boreogadus saida Lepechin, 1774), capelin (Mallotus villosus Müller, 1776), haddock (Melanogrammus aeglefinus Linnaeus, 1758), Atlantic herring (Clupea harengus Linnaeus, 1758), Atlantic salmon (Salmo salar Linnaeus, 1758), righteye flounders (Pleuronectidae Cuvier, 1816), etc., observed in the North Atlantic during the 1970s to the 1990s (Borisov et al., 2001). These species are the key food items in the diet of beluga, and their abundance and distribution determine the distribution of beluga whales (Klumov, 1939; Kleinenberg et al., 1964: 271, 301). A combination of anthropogenic (overfishing) and climatic (cooling period in the 1960s-1980s) factors in that period caused the catastrophic decline in the abundance of these fish species (Borisov et al., 2001).

It is known, that during the cooling period and the reduction in the productivity of the Barents Sea, the migration routes of the harp seal also changed. This pagophilic marine mammal species has a diet spectrum overlapping with that of the beluga whale and is also associated with ice. From 1978 to 1988, a mass immigration of harp seals to the coastal waters of Norway was recorded (Haug et al., 1991; Tynan \& DeMaster, 1997). The distribution of beluga whales was also noted to have changed in those years. The annual observations of marine mammals in western Murman (the Ainov Is- 
lands) from 1963 to 1973 resulted in only two sightings of single individuals. However, since 1978, when cases of abnormal mass migrations of harp seals were first recorded, belugas were also encountered here almost annually, sometimes in large groups (Tatarinkova \& Chemyakin, 1990).

It can be assumed that the reduction in catches in the 1960s-1980s and, probably, the overall decrease in the abundance of beluga whales were associated with an anthropogenic factor (overharvesting), while the decline in the number of beluga whales visiting their favorable coastal waters could be caused by a climatic factor (cooling period) and a reduction in their food supply. It is possible that a decrease in the size of fish stocks by itself could affect the abundance of beluga whales, but with a time delay. It is known that the population of the harp seal in the 1980s reduced because of the decline in the capelin abundance (Tynan \& DeMaster, 1997).

\section{Conclusion}

The present work provides long-term series of data on harvests of beluga whales in the White and Barents Seas, and the western part of the Kara Sea collected from the documents of Russian archives, as well as information on possible places of deposition of documents containing data on beluga whaling. The Northern Basin catch of 1964, found in our study, was almost twice as high as the earlier published figure for that year (Ognetov, 1999) and the recommended maximum allowable catch (Kleinenberg et al., 1964). This find allows us to draw a conclusion on the overharvesting of beluga whales, which may have substantially depleted the stock and affected subsequent catches in the Northern Basin. It also demonstrates the importance of work with original reports of fishery organizations. Such reports for the regions where scientific studies of beluga whales were quite rare, such as the Kara Sea, can serve as an important source of biological information on the species. For a comprehensive retrospective assessment of the status of beluga whale populations and identification of coastal key areas for summer stocks in the seas of the Russian Arctic, for verification and improvement of the already obtained data, a long-term study is required in all the above-listed regional archives.

ACKNOWLEDGEMENTS. We thank A.I. Zheludkova for her work in GAAO; A.A. Karcheva and R.Z. Chuklina from GANAO, and N.A. Vill' and M.V. Kashmakova from GAYaNAO - for their work with, search for, and systematization of the archived documents; D.M. Kuznetsova - for assistance with illustrations. We sincerely thank Dr. Yulia Ivashchenko and one Anonymous Reviewer for critical reading, valuable comments, and language editing, which clarified and significantly improved our manuscript.

\section{References}

[A historical description of the first-class stauropegial Solovetsky Monastery, compiled by Archimandrite Melety]. 1881. Reprint. 2011. 304 p. [in Russian].

[Acts of the Solovetsky Monastery for 1479-1571]. 1988. Leningrad. No.27. 28 p. [in Russian].

AGV [Arkhangel'skie Gubernskie Vedomosti]. 1857. No.35; no pages [in Russian].

AGV [Arkhangel'skie Gubernskie Vedomosti]. 1877. No.64. 6 p. [in Russian].

AGV [Arkhangel'skie Gubernskie Vedomosti]. 1879. No.4; no pages [in Russian].

Belov M.I. 1956. [Arctic navigation from ancient times to the middle of the $19^{\text {th }}$ century]. Moscow. 351 p. [in Russian].

Boltnev A.I., Grachev A.I., Zharikov K.A., Zabavnikov V.B., Kornev S.I., Kuznetsov V.V., Litovka D.I., Myasnikov V.G. \& Shafikov I.N. 2016. [Resources of marine mammals and their harvest in 2013] // Trudy Vserossiiskogo Nauchno-Issledovatel'skogo Instituta Rybnogo Khozyaistva i Okeanografii. Vol.160. P.230-249 [in Russian].

Boltunov A.N. \& Belikov S.E. 2002. Belugas (Delphinapterus leucas) of the Barents, Kara and Laptev seas // NAMMCO Scientific Publications. Vol.4. P.149-168.

Borisov A.A. 1907. [At the Samoyeds. From Pinega to the Kara Sea]. Saint Petersburg. 63 p. [in Russian].

Borisov P. 1926. [The beluga whale (Delphinapterus leucas) and the possible development of harvesting it] // Izvestiya Ivanovo-Voznesenskogo Politechnicheskogo Instituta. Vol.9. P.61 [in Russian].

Borisov V.M., Ponomarenko V.P. \& Semenov V.N. 2001. [Bioresources of the Barents Sea and fisheries in the second half of the 20th century] // Ekologiya promyslovykh vidov ryb Barentseva morya. Apatity. P.139-192 [in Russian].

Dmokhovskii A.V. 1931 (?). [The beluga whale of the White Sea]. Bibl. not found. Cited from: GAAO, f.1145, inv.1, c.51, sh.2 [in Russian].

Finsch O. \& Bram A. 1882. [A journey to Western Siberia]. Moscow. 551 p. [Russian translation].

Glazov D.M., Chernook V.I., Nazarenko E.A., Zharikov K.A., Shpak O.V. \& Mukhametov L.M. 2010. Summer distribution and abundance of belugas in the White Sea based on aerial survey data (2005-2008) // Collection of scientific papers of the $6^{\text {th }}$ Conference "Marine Mammals of Holarctic". Kaliningrad (11-15 October 2010). P.134-140.

Golenchenko A. 1936. [Catching beluga whales with a purse seine in the White Sea] // Za rybnuyu industriyu Severa. No.3. P.5 [in Russian].

Golenchenko A.P. 1963. [Some data on the distribution of beluga whales in the White Sea] // Rybnoye Khozyaistvo. No.11. P.28-31 [in Russian].

Haug T., Kreyer A.B., Nilssen K.T., Ugland K.I. \& Aspholm P.E. 1991. Harp seal (Phoca groenlandica) invasions in Norwegian coastal waters: age composition and feeding habits // ICES Journal of Marine Science. Vol.48. P.363-371.

Jefferson T.A., Leatherwood S. \& Webber M.A. 1993. FAO species identification guide. Marine mammals of the world. Rome: FAO. 320 p. 
Kleinenberg S.E., Yablokov A.V., Bel'kovich V.M. \& Tarasevich M.N. 1964. [Beluga whale: An experience of the monographic study of the species], Moscow: Nauka. 455 p. [in Russian].

Klumov S.V. 1939. [The beluga whale of the Soviet North (Raw materials base and harvesting)] // Trudy Vsesoyuznogo Nauchno-Issledovatel'skogo Instituta Rybnogo Khozyaistva i Okeanografii. Moscow: Krasnoe Znamya. Vol.12. P.1-79 [in Russian].

Krechkov G. 1924. [Beluga whaling in the Dvina Bay] // Severnoye Khozyaistvo. No.3. P.30-32 [in Russian].

Krupnik I.I. 1989. [Arctic ethnoecology] Moscow. 179 p. [in Russian].

Latkin N.V. 1892. [The Yeniseysk Governorate, its past and present]. Sankt Petersburg: Tipografiya V.A. Tikhanova. 175 p. [in Russian].

Lukin L.R. \& Ognetov G.N. 2009. [Marine mammals of Russian Arctic: analysis of ecology and fauna]. Yekaterinburg: UrO RAN. 204 p. [in Russian].

Maminov G.M. 1959. [Beluga harvest in the North]. Arkhangelsk: Arkhangel'skoye Knizhnoye Izdatel'stvo. 8 p. [in Russian].

Matishov G.G. \& Ognetov G.N. 2006. [The beluga whale Delphinapterus leucas in the Arctic seas of Russia: The biology, ecology, conservation, and use of the resource], Apatity: Izdatel'stvo Kol'skogo Nauchogo Tsentra RAN. 295 p. [in Russian].

Meschersky I.G., Chernetsky A.D., Krasnova V.V., Solovyev B.A., Udovik D.A., Shpak O.V., Glazov D.M. \& Rozhnov V.V. 2018. Mitochondrial lineages of the beluga whale Delphinapterus leucas in the Russian Arctic // Biology Bulletin. Vol.45. No.2. P.147-154.

[Notes on the fishing industry in northwestern Siberia]. 1824 // Sibirskii Vestnik. Sankt Petersburg. Part 3. P.289-308 [in Russian].

Ognetov G.N. 1987. [Ecological and morphological characteristics of the beluga whale in the Western region of the Soviet Arctic and the rational use of its stocks] // [Thesis of Candidate (Ph.D.) of Biological Sci. Degree]. Moskva: Institut Evolyucionnoi Morphologii Zhivotnykh imeni A.N. Severtsova. 155 p. [in Russian].

Ognetov G.N. 1999. Catch history, statistics and modern exploitation of beluga (Delphinapterus leucas) in the western Russian Arctic // Working paper SC/7/BN/21 presented to the NAMMCO Scientific Committee. 3 p.

Ognetov G.N. 2005. [The beluga whale of the Arctic seas of Russia: The population status and the resource potential] // Rybnoye Khozyaistvo. No.5. P.66-69 [in Russian].

Ognetov G.N. \& Potelov V.A. 1978. [Dynamics of beluga whales' migrations to the White Sea] // Ekologiya. No.4. P.78-85 [in Russian].

Ognetov G.N. \& Potelov V.A. 1982. [Beluga whaling in the White, Barents, and Kara Seas] // Rybnoye Khozyaistvo. Vol.12. P.51-53 [in Russian].

[On fisheries in Novaya Zemlya]. 1923 // Severnoye Khozyaistvo. No.7. P.101 [in Russian].

Ostroumov N.A. 1935. [On beluga whaling] // Khozyaistvo Severa. No.11. P.42-49 [in Russian].

[Report of the Arkhangelsk Governorate Statistical Committee]. 1876. Arkhangelsk. P.100 [in Russian].
[Reports and reviews of the Arkhangelsk Governorate Statistical Committee for 1874-1915]. 1875-1916. Arkhangelsk. [in Russian].

Rostislavin A.F. 1926. [Fisheries of the Mezen Coast]. Arkhangelsk. 174 p. [in Russian].

Savateev Yu.A. 1991. [Fishing and marine fisheries in Karelia] // Rybolovstvo i morskoi promysel v epokhu mezolita rannego metalla $\mathrm{v}$ lesnoi i lesostepnoi zone Vostochnoi Evropy. Leningrad. P.164-181 [in Russian].

Shpak O.V., Krasnova V.V. \& Meschersky I.G. 2018. White Sea (Russia) beluga stock // Report of the NAMMCO Global Review of Monodontids. 13-16 March 2017, Hillerød, Denmark. Annex 18. P.163-173. Available at https:// nammco.no/topics/sc-working-group-reports/

Solovyev B.A., Glazov D.M., Chernook V.I., Nazarenko E.A., Chelintsev N.G. \& Rozhnov V.V. 2012. Distribution and abundance of beluga whales (Delphinapterus leucas) in the White Sea and in the Southern part of the Barents Sea based on aerial counts in august $2011 / /$ : Collection of scientific papers of the 7th Intl. Conf. "Marine Mammals of Holarctic". Suzdal (24-28 September 2012). Vol.2. P.264-269.

Solovyev B.A., Shpak O.V., Glazov D.M., Rozhnov V.V. \& Kuznetsova D.M. 2015. Summer distribution of beluga whales (Delphinapterus leucas) in the Sea of Okhotsk // Russian Journal of Theriology. Vol.14. No.2. P.201-215.

[Studies on the state of fisheries in Russia]. 1862. Sankt-Peterburg. Vol.6. 163 p. [in Russian].

Tarasevich M.N. 1960. [Characteristics of beluga whales' approaches to shores] // Trudy Polyarnogo Nauchno-Issledovatel'skogo Instituta Rybnogo Khozyaistva i Okeanografii. Murmansk: Polyarny Nauchno-Issledovatel'skii Institut Rybnogo Khozyaistva i Okeanografii. Vol.12. P.146-153 [in Russian].

Tatarinkova I.P. \& Chemyakin R.G. 1990. [On sightings of marine mammals in the area of the Ainov Islands (Western Murman)] // Morskie mlekopitayushchie: Tezisy Dokladov $\mathrm{X}$ Vsesoyuznogo soveshchaniya po izucheniyu, okhrane i ratsional'nomu ispol'zovaniyu morskikh mlekopitayushchikh. Moscow. P.291-292 [in Russian].

[The memorial book of the Arkhangelsk Governorate for 1911]. 1912. 154 p. [in Russian].

[The account books of the Solovetsky Monastery in 15711600]. 2013 // Frantsuzova E.B. (compiler). Moskva, Sankt-Peterburg: Alyans-Arkheo. 194 p. [in Russian].

Tynan C.T. \& DeMaster D.P. 1997. Observations and predictions of Arctic climatic change: potential effects on marine mammals // Arctic. Vol.50. No.4. P.308-322.

Webermann E.A. 1914. [Whaling in Russia] // Izvestiya Moskovskogo Kommercheskogo Instituta. Vol.2. P.1-306 [in Russian].

Zhilinskii A.A. 1917. [Marine fisheries of the White Sea and the Arctic Ocean]. Petrograd: Tipographia tovarishchvestva A.F. Marks. 148 p. [in Russian].

Zhilinskii A.A. 1951. [Harvesting of marine mammals in the White Sea]. Petrozavodsk. 42 p. [in Russian].

Zhitkov B.M. 1922. [The Russian Arctic Sea and its significance]. Moscow. 14 p. [in Russian].

Zhitkov B. \& Buturlin S. 1901. [Across the Russian North] // Zemlevedeniye. Vol.3-4. P.29-206 [in Russian]. 